\title{
Christian Jürgensen Thomsens rejse til hertugdømmet Slesvig i sommeren 1863
}

\author{
af Stine Wiell
}

I august 1863 besøgte Oldnordisk Museums direktør Christian Jürgensen Thomsen Nydam mose. Her var udgraveren Conrad Engelhardt i færd med at fremdrage de i dag så berømte fund. Museumsdirektøren berettede om sine oplevelser i ét af de breve, han sendte fra rejsen til Slesvig. Det viser, at han i sin alderdom fik øje for arkæologiske udgravningers betydning. Museumsinspektør Stine Wiell har fundet de hidtil ukendte breve og fortæller samtidig om Thomsens betydning $\mathrm{i}$ arkæologiens og museernes historie.

Mine kare Brodre og Venner

Flensborg Onsdag den 12. Aften

Den forste Station af min lille Rejse er jeg $n u$ på. Omendskjøndt det var det skønneste Vejr, nød jeg dog ikke fuldkommen de smukke Egne vi sejlede igennem, thi jeg folte en fuldkommen Mangel på Appetit og levede en hel Dag på to smaa Glas Portvin og en Kop Caffe. Jeg havde ved Telegraph $i$ Korsor fået at vide, at jeg burde ej gå videre end til Sønderborg - og havde alt besluttet at blive dér, men Engelhardt og hans Vert, en Skolelarer og en rig Landmand, der havde varet $i$ Museet $i$ Kjøbenhavn, opmuntrede mig alle til at tage til Sottrup, $i$ hvis Narhed Udgravningen i Ny Dam Mose foretages, og var vidt fremskreden. Kjøreturen [og] den venlige Modtagelse jeg fandt hos Beboerne i Forbindelse med et Pulver gjorde, at jeg noeste Dag befandt mig bedre og kunne tilbringe den meste Tid på Mosen lige overfor Gravningen, som var interessant og langt vanskeligere end Herrerne ved de gronne Borde tanke dem. Det blev snart tydeligt, at hvad der nu var Mose, havde varet en Del af Sundet imellem Als og Slesvig. Det naste jeg saa var, at Sagerne lả lige på Havbunden. Det var tydeligt ved hvid Sand hvori mangfoldige Skaldyr af de som endnu findes $i$ det Als omgivne Vand. Det noeste som blev mig klart var, at Oldsagerne ikke ere komne i Mosen, men at denne må have dannet sig bagefter, efter at Forbindelsen med Sundet var ophort.

Det eneste som jeg kunne tanke mig havde frembragt den hojst besynderlige og ellers uforklarlige Måde jeg så Sagerne ligge på, var at de ved Strømninger $i$ Vandet eller om Vinteren ved Isgang kunne vare bragt ud af deres forste Leje, 
thi det gik nu snart på langs snart på tvars snart ovenpå hinanden, snart Dele der ojensynlig horte sammen langt fra hinanden. Her en Del af et Svard, tre Alen derfra et andet Stykke og dog ufuldstandigt. Et Lerkar af ualmindelig Form blev funden, men hvorledes [!]. Det var brudt midt over, den anden Halvdel fandtes 15 Alen fra hin den forste optagne. Det markeligste som jeg så blive optagen i min Narvarelse var 8 Langbuer. Uagtet andre Stykker Beviklinger af Snore var bevaret på alle 8 [, var] ikke mindste Levning af Strengen tilbage, men vel Indsnit til at befaste dem, og således [er der] endnu mange Gåder at lose og forklare.

De markeligste Stykker forekom mig at vare et Pragtsvard med Solvhåndtag og et Svard, hvorpå Forfardigerens Navn var indslàet med et Stempel. Navnet vil kunne lases, når det bliver lidt mere rengjort, men det var umulig ude på Mosen.

Arbejderne var meget ovede, men det behoves og, thi det er utroligt, hvor skjort Traet er og dertil Svampagtig. For at finde mindre Ting som Mynter, Spander og deslg måtte den nederste Mosejord gjennemsoges med Handerne, ja nasten altes med dem.

For at optage Spyd der var 10 Fod lange, måtte man folge Retningen de laa $i$, og undertiden fandtes dog ikke den vigtige Jernspydspids.

Man havde gravet $i 14$ Dage og ventede at kunne fortsatte $i 10$ Dage. Man havde fundet meget, men ikke et eneste Stykke som omstodte de Beregninger og Formodninger, man havde om Tiden Sagerne tilhorte - det gladede mig at se, og jeg er ikke uden Haab, at et eller andet Overordentlig vil fremkomme.

$\mathrm{Nu}$ indser jeg meget lettere de Vanskeligheder, som der er forbunden med at optage slige Mosefund, og som vist have varet ligeså vanskeligt ved Allesøe. ${ }^{1}$

Det er ingen ringere end Oldnordisk Museums direktør Christian Jürgensen Thomsen, som skrev dette i Flensborg den 12.august 1863. Som man kan forstå var det ikke planlagt, at Thomsen skulle besøge den arkæologiske udgravning i Nydam mose på Sundeved.

Rejsen gik til Vestjylland og til hertugdømmet Slesvig, og blev en af hans sidste. Han havde flere arinder, deriblandt et besøg hos en af sine gamle elever, inspektøren for "Den kongelige Samling af Nordiske Oldsager « i Flensborg, arkæologen Conrad Engelhardt. Thomsen ønskede at se museet, som netop var nyordnet $\mathrm{i}$ regeringsbygningen $\mathrm{i}$ byen. Han elskede at rejse og havde igennem et langt liv rejst Europa tyndt, når der havde været lejlighed dertil. Det var, når han skulle deltage $\mathrm{i}$ auktioner, bese privatsamlinger eller museer.

Det ovenfor citerede brev er usædvanligt på flere måder. Ikke blot derved, at det i sig selv supplerer de hidtil kendte kilder til udforskningen af Nydam mose. Det røber, at Thomsen ved selvsyn havde forstået, at betydende iagtta- 
Christian Jürgensen Thomsen (1788-1865). Foto C. Piil's photogr. atelier, Kobenhavn, 1864. Det kongelige Bibliotek.

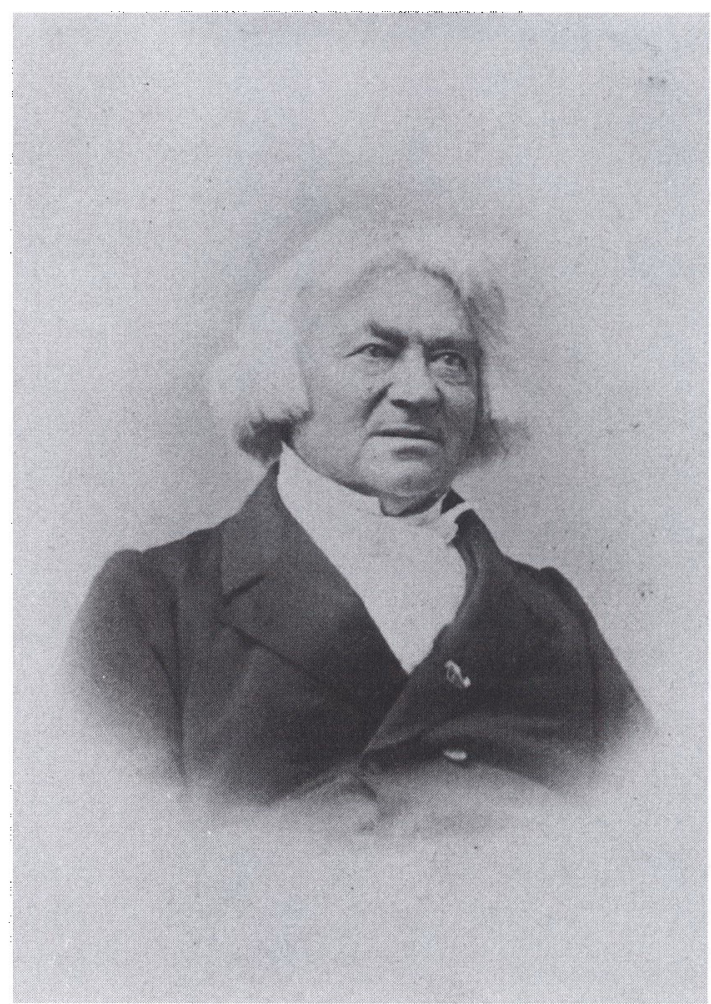

gelser gøres ved arkæologiske udgravninger og i moser under særdeles vanskelige arbejdsforhold af erfarne folk. Og endda var arbejdsforholdene i Nydam ikke noget særligt problem for den ansvarlige udgraver, mosepionèren Engelhardt. I Thorsbjerg mose i Angel havde han hvert år siden 1858 ladet dræne således, at hans folk kunne arbejde i dybder, der selv i dag imponerer nutidens garvede feltarkæologer. Visse af de oldsagførende lag i Thorsbjerg mose lå i mere end 5,50 meters dybde. Det var på grund af mosens bevægelser slet ikke ufarlige dybder at arbejde i. Hvordan Engelhardt præcist løste dræningsproblemerne i Nydam ved vi ikke. Men det står fast, at forholdene i Nydam var betydeligt nemmere at håndtere. Det var fjerde saison, der blev gravet i Nydam mose. Denne sidste sommer blev der, mens Thomsen var til stede, arbejdet $\mathrm{i}$ op til 1,50-2 meters dybde på Jørgen Hanssens moselod. Ugen efter skiftedes til Jørgen Jørgensens lod, hvor den store egebåd blev frigravet $\mathbf{i}$ nogenlunde samme dybde. ${ }^{2}$ 


\section{De omtalte personer}

De personer Thomsen nævner ved deres erhverv er skolelæreren og degnen $\mathrm{i}$ Vester Sottrup Nis Kuntz. Kuntz' grundige dagbog med fyldige notater om udgravningerne er bevaret på Landsarkivet i Aabenraa. Uddrag relevante for krigen 1864 er for mange år siden offentliggjort i Sønderjysk Månedsskrift. Man kan også læse i Kuntz' dagbog fra 1859, at han var blevet gift den 31.juli 1859 med Cathrine Hanssen, og at familien Engelhardt havde været med til brylluppet. Ved sit giftermål var Kuntz blevet svoger til den rige landmand på Nørremølle, Christen Hanssen. Dennes korrespondance med en yngre broder Hans Peter er også kendt læsning for så vidt angår de arkæologiske udgravninger i Nydam. ${ }^{3}$ Thomsen kalder ham også for "mølleren«. Mølleren hentyder til hans privilegium som mølleejer og brændevinsbrænder på gården Nørremølle. Her i Sottrup blev Thomsen ikke så lidt feteret. Han nød det og skrev:

»Hvad jeg ikke ventede var, at man i Sottrup indbød mig at besøge Mølleren for at se de chinesiske Sager, han havde og som jeg fandt selv hos hans Svoger Skolelæreren, jeg boede hos. Disse Sager var alle af en bedre Slags Silketøjer, udmærkede Broderier, chinesisk Possementmager Arbejde, hvoraf man forærede mig Prøver, japanske Porcelainer osv osv - En Broder til Mølleren er nu en anset Købmand i Shanghai, havde besøgt sin Familie og bragt Foræringer til alle sine 9 Søskende - Den Dag måtte jeg enten jeg ville eller ei spise 5 Gange, thi hvor jeg kom var strax en Anretning dér.«

De ukendte personer, Thomsen nævner, er "Herrerne ved de grønne Borde«. Man forstår hans generalisering som en personlig afstandtagen til både dem og deres grønne borde. I et andet brev og $i$ en anden sammenhæng anvendte han udtrykket om de mænd, som havde bestemt, at Universitetsbiblioteket skulle have lukket om sommeren, hvor netop alle tilrejsende kunne komme og se bibliotekets herligheder. ${ }^{4}$ I de tidligste år på loftet over Trinitatis kirke havde den første samling af oldsager, som Thomsen ordnede, bygningsfællesskab med Universitetsbiblioteket. Han holdt samlingerne åbne om sommeren og ovenikøbet med gratis adgang for de besøgende. Begge dele var sikkert medvirkende til deres publikumssucces. Men universitetet mente, at stedet blev belastet af de mange besøgende. Og Thomsen måtte finde andre lokaler. Han, der som museumsmand var selvlærd og uden akademiske grader, bevarede

Der kendes kun ganske få jernsvard med greb af solv fra Nydam. Det er derfor sandsynligt, at det centralt placerede svard med timeglasformet greb, belagt med bånd af solv, nr. 3 og $3 a$, er netop dét svard, Thomsen så blive udgravet i mosen den 12. august 1863. Efter Conr. Engelhardt: Nydam Mosefund 1859-1863 med kobberstik af J. Magn. Petersen, Kjøbenhavn 1865 (genudgivet 1970). 


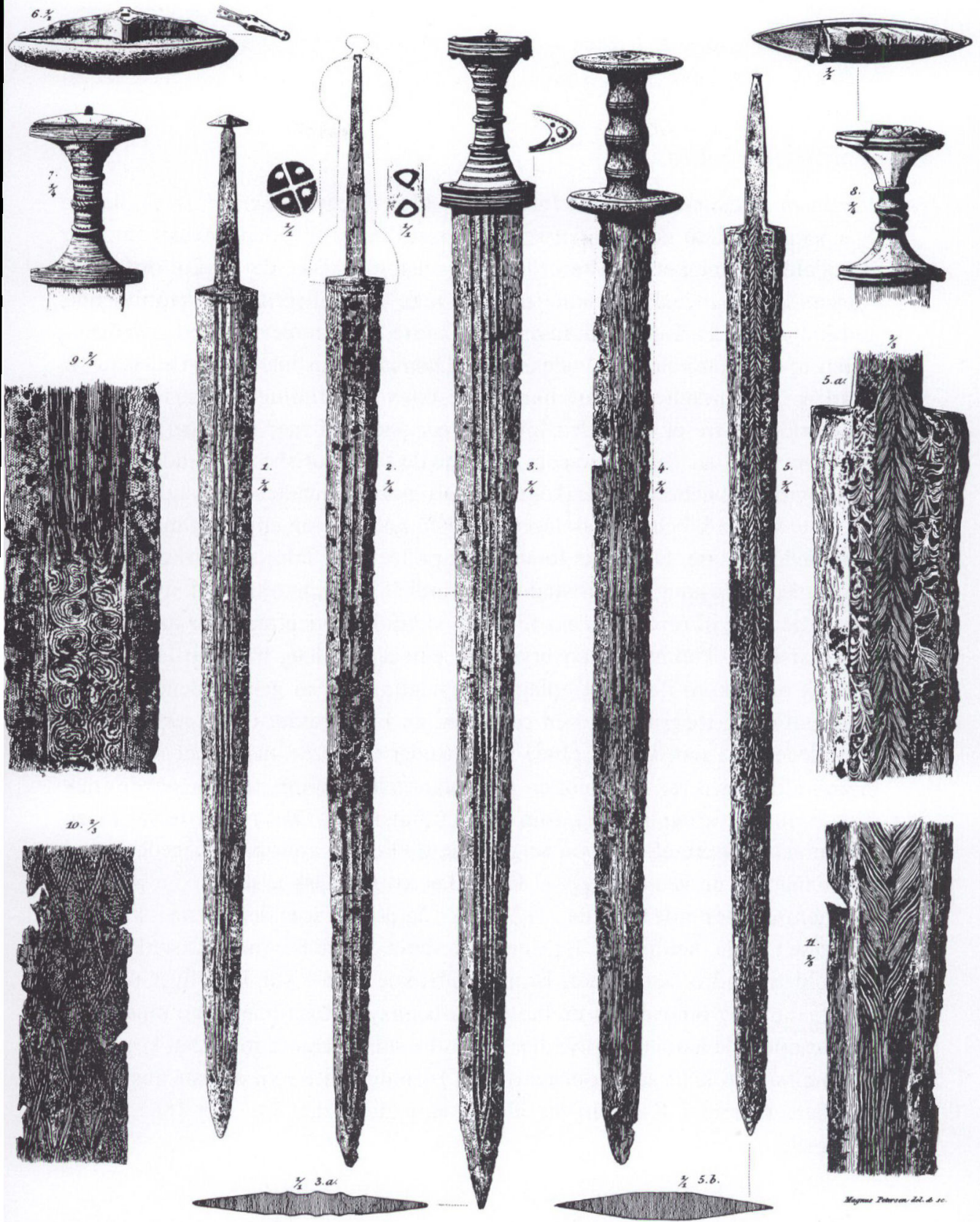


hele livet en vis aversion mod de akademikere, som med deres gerning ikke vovede sig uden for deres eget lukkede miljø og ikke kom længere end eksamensbordets grønne klæde.

\section{Thomsens betydning}

Læren om tidsrækkefølgen, kronologien, blev i begyndelsen af 1800 tallet et hjælpemiddel til at skabe en anskuelig fremstilling af fortiden. Mediet var, når det gjaldt menneskets ældste historie, forhistorien, ikke det trykte ord, eller bogen, som man måske kunne tro det, men 1800tallets nye folkeoplysende redskab - museet. Det er Thomsens fortjeneste, og han blev dermed grundlæggeren af den arkæologiske videnskab i Danmark. En lille bog "Ledetråd til nordisk Oldkyndighed«, hvori han senere skrev om ordningen af de forhistoriske perioder i tre på hinanden følgende perioder, var med til at befæste hans position. Han var den første som ordnede de forhistoriske genstande efter en tids- og materialebestemt rækkefølge. Han gjorde »urtiden«, der indtil da for de fleste var en bibelhistorisk legende, til en »oldtid« og en del af menneskets materielle historie. Det skete første gang på loftet af Trinitatis kirke engang i 1820erne, næste gang på Christiansborg slot i 1832-34, hvor han fik nye lokaler og tredie gang i Prinsens palæ i 1855. "Ledetråd«, som eftertidens arkæologer blot har kaldt Thomsens banebrydende artikel fra 1836, blev hurtigt oversat til tysk og udkom i et stort oplag. Efter iagttagelser af genstandene inddelte han oldtiden $i$ tre perioder $i$ en stenalder, en broncealder og en jernalder og udstillede dem som sådan. Disse tre perioder udgjorde tilsammen Oldtiden. Men inddelingen var ikke blot en grov materialesortering, tingene havde træk i sig som pegede i en retning, som viste en udvikling. Da forst dette var klart, kunne han sortere efter, at en ting havde træk $i$ sig, som både pegede bagud og fremad og derved opbygge et finmasket kronologisk system.

Thomsen mestrede allerede i 1820erne - og derved som den første - kunsten at "læse i ting«, netop dét, der siden har været alle museumsfolks særkende, i forhold til andre historikere. Hans foretrukne medie var hele livet museet. Han skabte og omordnede de fleste i København. Positionen som museernes nestor opnåede han $\mathrm{i}$ et forløb, der begyndte som sekretær for "Den kongelige Commission til Oldsagers opbevaring « $\mathrm{i} 1816$ og endte som øverste ansvarlige for flere museer i Københavns hjerte. Han døde den 21, maj 1865, 76 år gammel. $^{5}$ 


\section{Thomsens børnebørn}

Det grundlæggende arbejde med »treperiodesystemet« lå omtrent fyrretyve år forud for den aften i Flensborg, hvor Thomsen sad og skrev til sin familie og sine medarbejdere i København. Der var gået så mange år, at Thomsen endog havde fået børnebørn, skønt han levede ugift hele livet. Hvordan dét kunne gå til, forklares ikke med ungdommelige sidespring, der kunne have ført til faderskab og nu bedstefaderskab. Thomsen opfattede de museer, som han havde skabt, som sine »børn«, og følgelig også de museer, som deraf opstod, som sine »børnebørn«.

»Børnebørnene« var samlingerne i provinsen, og vigtigst blandt disse var de to samlinger i hertugdømmerne Slesvig og Holsten. Eldst var Oldsagssamlingen i Kiel, skabt i 1834 på grundlag af en deponering på omkring 300 oldsager og middelalderlige genstande fra Det Oldnordiske Museum i København. Så fulgte Samlingen i Flensborg, der nu 11 år gammel forestod de omfattende arkæologiske udgravninger i Nydam mose. Flensborgsamlingen var grundlagt i 1852 og var allerede fra begyndelsen landets største samling udenfor København. På denne tjenesterejse var et af hovedformålene for Thomsen at tage den seneste nyopstilling $\mathrm{i}$ øjesyn. ${ }^{6}$

Foruden at besøge Flensborgsamlingen besøgte Thomsen i 1863 også samlingen i Ribe. Den var grundlagt i 1855 , men endnu ganske ubetydelig. Thomsen anvendte en halv dag i Ribe, hvor han nåede at bese både skolens samling af etnografiske genstande, en tilsvarende lille samling hos en privatmand, og en lille samling af oldsager »ved hospitalet«. Den antikvariske Samling i Ribe kunne efter tabet af hertugdømmerne smykke sig med navnet $"$ Danmarks ældste provinsmuseum«.

Efter grundlæggelsen af samlingen i Ribe fulgte samlingerne i Odense og Århus i 1860 og året efter endnu en samling i Viborg. Nogle måneder før Thomsens rejse til Slesvig og Vestjylland blev der også grundlagt en samling i Ålborg. Alle på nær Flensborgsamlingen var grundlagt på initiativ af velmenende lokale mænd fra den lavere embedsstand. Flensborgsamlingens fundament hvilede derimod $i$ et rent statsligt tiltag, men med justitsråd Claus Jaspersens kostbare lokale oldsagssamling fra Slesvig som grundpille. Alle var de støttet af deponeringer af oldsager fra Det Oldnordiske Museum i København, mindst naturligvis samlingen i Flensborg, som allerede fra begyndelsen var langt den største. 


\section{Rejseruten}

Thomsens rejse varede blot $11 / 2$ uge, men han nåede både rundt i Slesvig og kom tværs over Jylland. Han gennemførte de faglige ærinder, som han havde planlagt. Han nåede også at foretage et familiebesøg. Ovenikøbet nåede han at blive forbavset og engageret $i$, hvad han uventet oplevede $i$ Nydam mose.

Fra København tog han jernbanen til Kørsør. Herfra sejlede han med dampskib til Sønderborg, kørte til Sottrup, hvor han overnattede, sådan at han næste dag kunne tilbringe det meste af dagen $\mathrm{i}$ mosen. Men han nåede også rundt i sognet hos storbonden og hos præsten og blev derefter sammen med Engelhardt kørt ind til Flensborg for at bese museet og de nyopstillede mosefund. "Jeg fornøjede mig over den smukke og i visse dele enestående overordentlige Samling «, skrev han i det første brev. Næste dag fortsatte han til Ekernførde.

Derfra begyndte han om fredagen, fire dage efter afrejsen fra København, på det næste brev. Han tog det med sig og fortsatte med at skrive på det dagen efter i Slesvig by. Det blev fuldendt i Flensborg om søndagen. Helligdagen anvendtes iøvrigt til at høre gudstjeneste på dansk og gøre endnu et besøg i oldsagssamlingen sammen med Engelhardt. En spadseretur til Bissens løvemonument på kirkegården var dernæst planlagt. Men han gik fejl af vejen og nåede i stedet flere privatvisitter. Bl.a. fandt han den 78-årige agentinde Christiansen siddende $\mathrm{i}$ sin have. ${ }^{7}$ Thomsen, der hyppigt, når han var på rejse, målte sit eget helbred i forhold til andres, mente, at den kun 3 år æaldre kone var xldet. Samme dag rejste han videre via Aabenraa over Haderslev til Vestjylland. Tilbagevejen skete med postvognen $i$ et imponerende tempo via Kolding til Middelfart.

Det var sikkert en anstrengende rejse at gennemføre for en 75årig, når man betænker datidens lidet komfortable transportmuligheder. Thomsen foretrak da også de helt moderne transportmidler, dampskibe og jernbaner, frem for kørsel på landevejen f.eks. med postvognen. Hvis man gør sig den ulejlighed at slå op i samtidens aviser, kan man erfare, at Thomsen sejlede fra Korsør mandag den 10. august med dampskibet "Diana «. Det sejlede på ruten KorsørFlensborg og anløb undervejs Svendborg, Sønderborg og Brunsnæs. Fra Ekernførde benyttede han jernbanen, men han måtte tage landevejen til Haderslev, ligesom turens længste træk tværs over Jylland både frem og tilbage nødvendigvis måtte foregå med postvognen. Han kunne være blevet i Kolding, men havde undervejs følt, at han havde kræfter til at fortsætte. 


\section{Boet efter Peter von Timm}

Et andet hovedmål for rejsen var et besøg i Ekernførde. Her gennemgik Thomsen et dødsbo, som indeholdt en stor privatsamling tegninger, malerier, kobberstik, mønter, bøger o.s.v. Det var boet efter en af hans gamle bekendte premierløjtnant og forhenværende toldkontrollør Peter von Timm. Han var kendt i Slesvig som en stor samler og havde foretaget antikvariske rejser i hele hertugdømmet. ${ }^{8}$ Hans oldsagssamling var allerede i 1859 indgået i Flensborgsamlingen, men hvad nu med alt det andet?

Timm havde stort set samlet på alt og ovenikøbet også gemt alt. På sine ældre dage havde han ifølge Thomsen lidt så meget at gigt, at han ikke havde kunnet overkomme hverken at pleje eller at forædle sine samlinger. Det betød, at de forelå ikke blot i stor uorden, og i den rækkefølge som tingene var erhvervet. I nogle tilfælde var tingene end ikke udpakket. I sit indhold var det hele af meget uhomogen kvalitet. Alt dette generede den pertentlige Christian Jürgensen Thomsen, som havde brugt hele sit liv på at ordne og sortere. Timms samlinger omfattede foruden ca. 50 malerier store samlinger af kobberstik i mapper, kasser og skuffer, samt tegninger i stor mængde. Særligt glædede Thomsen sig over et skønt aftryk af den kendte 1600tals kobberstikker Haelwegs stik af Christian den 4. "Alt hvad man ellers kan vise af gamle Aftryk vil blegne ved siden af dette.« mente Thomsen.

Det er en guldaldertradition at samle på mønter. Møntsamlinger havde Thomsens særlige bevågenhed. Han havde samlet, siden han var ganske ung og ejede nu privat en af landets største og rigeste møntsamlinger. Karrieren for Thomsen var faktisk begyndt ved de københavnske møntauktioner, hvor man tidligt havde lagt mærke til hans kloge indkøb og store indsigt i numismatikken. Timms møntsamling fyldte 8 skuffer. Den bestod af nogle få danske middelaldermønter. Andre var fra den antikke oldtid, og endelig næunte Thomsen $i$ brevet herom også nogle nyere franske mønter.

Thomsen var beskæftiget med at gennemgå Timms samlinger en dags tid. Det trættede ham at gennemgå uordentlige samlinger, og brevet efterlader intet indtryk af, om noget fra Timms samlinger blev erhvervet. På vej tilbage til Flensborg gjorde han ophold i Slesvig, hvor han beså de to klostre. I det adelige frøkenkloster, St. Johannes i byens østlige del, var kun kirken bevaret fra middelalderen. Det andet, "Das Graue Kloster" var nu indrettet som hospital. Alt i kirken var ganske nyt. Også dét skuffede ham. 


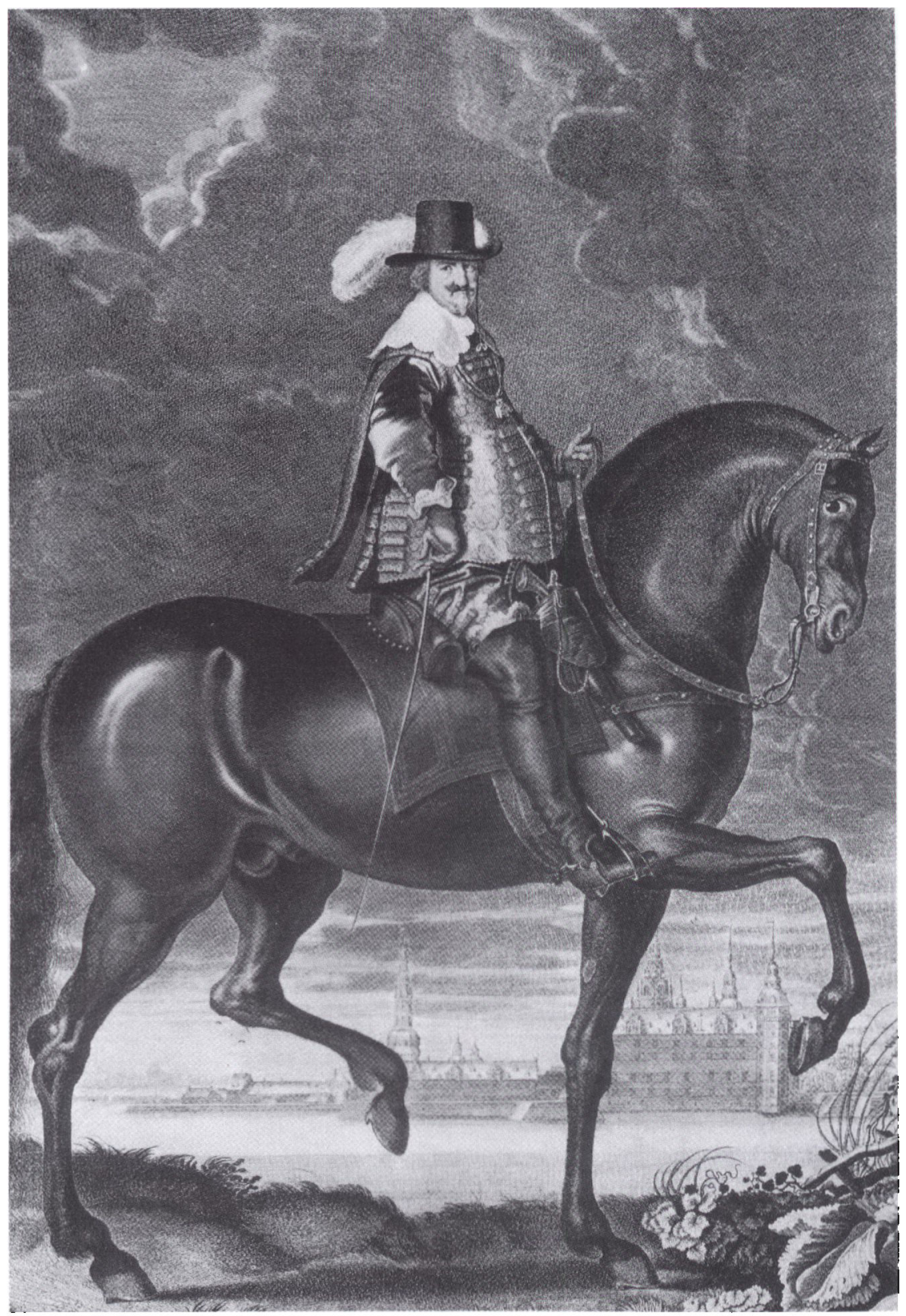

Albert Haelweghs kobberstik fra 1643-44 af Christian IV, som Christian Jürgensen Thomsen blev begejstret for $i$ boet efter Peter von Timm. Gengivet efter Povl Eller: Kongelige portratmalere $i$ Danmark 1630-82, 1971 s. 446. 


\section{Den skarpsindige iagttager}

De bevarede breve fra Christian Jürgensen Thomsens rejse viser, at han var professionel til fingerspidserne. Det fremstår overbevisende i omtalerne fra Ekernførde og Nydam. Når han selv arbejdede, d.v.s sorterede i Timms bo, søgte han både at iagttage og konkludere. I Nydam, hvor han blot så til, gjorde han det samme, søgte at forstå og forklare. Det var første gang han overhovedet var på en arkæologisk moseudgravning. Han formåede at give denne oplevelse umiddelbart og levende videre, som han opfattede den. Han forstod ikke kun de praktiske besværligheder forbundet dermed, men også, at de iagttagelser, man skal gøre undervejs, er vigtige for forståelsen af fundet, og han forsøgte selv at fortolke. Derfor er det spændende læsning. Sandlaget med skallerne forklarede han på den måde, at nedlæggelsen var foregået $\mathrm{i}$ åbent vand, og at vind og vejr havde påvirket lagringen af oldsagerne, indtil mosen lukkede sig om dem. I denne forbindelse spiller det en mindre rolle, om det var saltvandsskaller eller ferskvandsskaller, han så. I dag afvises det grundigt, at der i jernalderen var søværts forbindelse fra "mosen « og østpå. ${ }^{9}$ For Thomsen og for Engelhardt var der ingen tvivl, den nemmeste måde var at sejle, mens der endnu var forbindelse i denne retning ned til Alssund.

Thomsens betragtninger over dét, han så i mosen, og hvordan han tolkede det, er alligevel særdeles skarpsindige. Det er netop disse bemærkninger, som giver hans øjenvidneskildring fra Nydam mose mere end kuriositetens interesse.

\section{NOTER OG HENVISNINGER}

1. Tre breve i et særligt læg mærket «Thomsens rejse til Slesvig og Vestjylland» findes i Nationalmuseet, Oldtid og Middelalder, Arkivet vedr. museumshistorie før 1892: Breve fra Christian Jürgensen Thomsen.

Andre breve fra denne rejse findes dog også andre steder i samme arkiv, men ligger i modtagernes arkiver. Citater er så vidt muligt bragt ordret, men med en nyere stavemåde. Thomsens mangelfulde tegnsætning er ændret af hensyn til forståeligheden. Hvor det for forståelsen har været nedvendigt at indsætte supplerende ord, er det sket i skarp parentes.

2. I Jørgen Hanssens lod opgives dybden til mellem 5 og 7 fod i Berlingske Tidende, den 12.august 1863. I Jørgen Jørgensens lod opgives funddybden i samme avis den 24 . august 1863 til omtrent 7 fods dybde. Engelhardt opgiver de samme dybder i publikationen fra 1865.

3. Nis Kuntz' dagbog er bevaret på Landsarkivet i Aabenraa, P. 423. - Peter Beck: Om udgravningerne i Nydam mose, Sønderjysk Månedsskrift bd. 50, 1974, p 162ff. - Der henvises også til H.P.Hanssens erindringer: Et Tilbageblik, bd 1-4, København 1928 - 1934.

4. Brev til historikeren Vedel Simonsen, Elvedgaard på Fyn den 23. juni 1857. Efter Victor Hermansens arkiv angående Christian Jürgensen Thomsen, Det kongelige Bibliotek, Håndskriftafdelingen Ny kgl.Saml. 4546, kps 10.

5. Hele årgangen af tidsskriftet "Årbøger for Nordisk Oldkyndighed og Historie« 1988 er et mindeskrift for Christian Jürgensen Thomsen, udgivet i 200året for hans fødsel. Bogen rummer en lang række artikler om de seneste års Thomsenforskning. 
6. Victor Hermansen gør i Tredelingen og Odense, Odense 1960, opmærksom på at en lille samling på 63 oldsager allerede i 1818 var blevet deponeret på Stiftsbiblioteket i Odense. Men den var næsten blevet glemt, fordi den ikke blev vist frem. End ikke de mænd som i 1860 ville grundlagge en oldsagsamling $\mathrm{i}$ Odense kendte til den gamle deponering.

7. Thomsen fortalte, at de fik en snak om gamle og nye tider. Agentinden ejede som enke efter Andreas Christiansen jr. et af Flensborgs største handelshuse. Thomsen må have kendt familien længe, idet han som leder af det Thomsenske handelshus i København i mange år havde færdedes i skibsrederkredse.

8. Den nordslesvigske del af Peter von Timms antikvariske rejse foretaget $i 1847$ er udgivet $i$ dansk oversattelse ved Jørgen Rieck i tidsskriftet Lagast over to årgange, i hhv 1986 og 1987.

9. Niels Bonde, Charlie Christensen, Flemming Rieck og Peter Vang Petersen: Jernalderbåde og Våbenofre, Nationalmuseets Arbejdsmark 1990. Afvisningen er begrundet i talrige naturvidenskabelige boreprover, foretaget i forbindelse med de genoptagne Nydamundersagelser i 1989. Opfattelsen er tidligere formuleret af jernaldermoseforskerne Jørn Lønstrup og Jørgen Illkjær i en mindre lokalhistorisk artikel. » Nydam - nye udgravninger ? ", Årsskrift for Sottrup sogn 1982. 